\title{
PERAN GURU BIMBINGAN DAN KONSELING DALAM MENINGKATKAN MOTIVASI BELAJAR PESERTA DIDIK DALAM MENGHADAPI UJIAN NASIONAL KELAS XI (STUDI KASUS DI SIMAN 2 KOTA TEGAL)
}

\section{The Role Of Guidance And Counseling In Improving Students 'Learning Motivation In Facing The Class XI National Exam (Case Study In SMAN 2 Kota Tegal)}

\author{
'Sesya Diaz Mumpuni
}

I Universitas Pancasakti, Tegal, Jawa Tengah, Indonesia

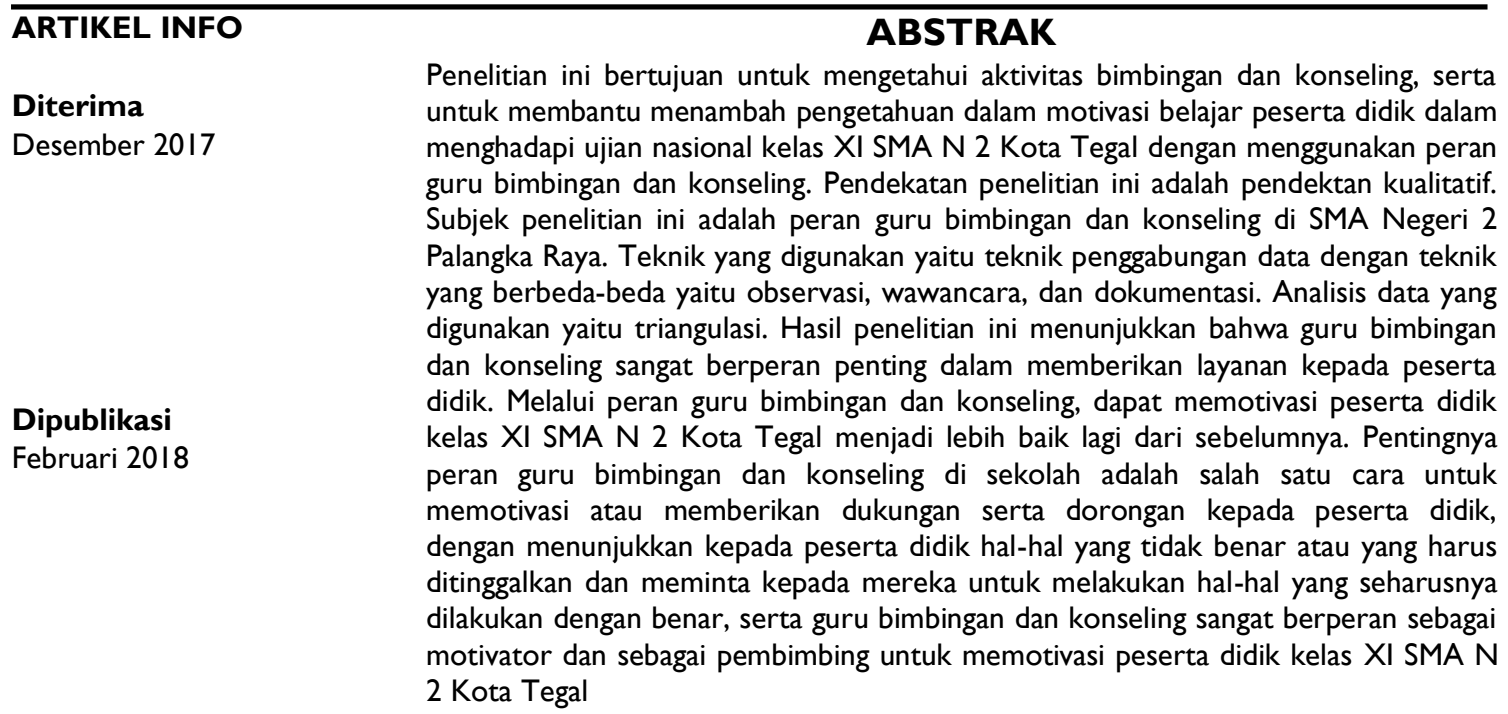

*E-mail: sesyadiazm@gmail.com

Orchid:
Kata Kunci: Peran Guru BK, Motivasi, dan Ujian Nasional

\section{ABSTRACT}

This study aims to determine the activities of guidance and counseling, as well as to help increase knowledge in learning motivation of students in facing the national exam in class $X I$ of SMA N 2 Kota Tegal by using the teacher's role of guidance and counseling. The approach of this research is qualitative assessment. The subject of this study was the role of the guidance and counseling teacher in Palangka Raya 2 High School. The technique used is the technique of combining data with different techniques, namely observation, interviews, and documentation. Analysis of the data used is triangulation. The results of this study indicate that guidance and counseling teachers play an important role in providing services to students. Through the role of teacher guidance and counseling, it can motivate the eleventh grade students of SMA N 2 Kota Tegal to be even better than before. The importance of the role of guidance and counseling teachers in schools is one way to motivate or provide support and encouragement to students, by showing students things that are not right or that must be left behind and ask them to do things that should be done correctly, as well as guidance and counseling teachers are very instrumental as motivators and as mentors to motivate students of class XI SMA N 2 Tegal City.

Keywords: Role of BK Teachers, Motivation, and National Examination 


\section{PENDAHULUAN}

Menurut Nurul Hidayah (2013: 5) Ujian Nasional sepertinya merupakan jalan yang dianggap mudah oleh pemerintah dalam menentukan indikator dan standar mutu. Komponen UN yang melibatkan banyak kepentingan yang terkadang menjadi pemicu dari hilangnya arah sebuah kebijakan. Ujian Nasional memiliki mekanisme jejaring dan komponen multi system. Mulai dari perencanaan, pengadaan soal/logistik ujian, penetapan nilai, distribusi soal sampai pada monitoring dan evaluasi, karenanya dibutuhkan anggaran yang tidak sedikit karena melibatkan berbagai kepentingan.

Menurut Alimuddin S Miru (2009: 2) Kesuksesan pelaksanaan pendidikan di sekolah dipengaruhi oleh banyak faktor, salah satunya adalah faktor peserta didik yang merupakan subjek didik yang turut menentukan keberhasilan proses pendidikan. Untuk mengoptimalkan keberhasilan dalam pendidikan sekolah, maka semua faktor yang berkaitan dengan proses pendidikan atau proses belajar, harus diperhatikan sehingga dapat membantu tercapainya tujuan yang diharapkan. Tujuan yang dimaksud adalah tercapainya prestasi belajar yang tinggi. Faktor motivasi belajar pada peserta didik. Motivasi dikatakan sebagai sesuatu yang kompleks, karena motivasi akan menyebabkan terjadinya perubahan energi yang ada pada diri manusia, sehingga akan berpengaruh terhadap gejala kejiwaan, perasaan dan juga emosi, untuk kemudian bertindak atau bersikap terhadap sesuatu.

Peran guru BK atau guru pembimbinglah yang sangat besar. Guru BK sebagai representasi pendidik jelas memiliki rasional yang kuat untuk menyampaikan pendidikan karakter pada peserta didik artinya dipundak guru BK pendidikan karakter menjadi salah satu tugas dan kewajiban yang harus dilaksanakan dalam memberikan layanan bimbingan dan konseling. Terkait pendidikan karakter di sekolah guru BK mempunyai tugas yang cukup penting yaitu harus dapat memfasilitasi pengembangan dan penumbuhan karakter serta tanpa mengabaikan penguasaan hard skill lebih lanjut yang diperlukan dalam perjalanan hidup serta dalam mempersiapkan karier (Yanti, 20I5: 3). Seorang guru BK harus profesional sebagai tenaga pendidik disekolah. Menurut UU RI No. 20 Tahun 2003 pasal I ayat 4 "Pendidik adalah tenaga kependidikan yang berkualifikasi sebagai guru, dosen, konselor, pamong belajar, widyaiswara, tutor, instruktur, fasilitator dan sebutan lainnya yang sesuai kekhususannya serta berpartisipasi dalam penyelenggaraan pendidikan" (Yanti, 20I5: 3).

Berdasarkan fenomena yang saya temukan di lapangan peneliti tertarik mengangkat penelitian yang berjudul "Peran Guru Bimbingan dan Konseling dalam Meningkatkan Motivasi Belajar Peserta Didik". Peran guru BK dalam peminatan peserta didik sangat penting untuk membantu peserta didik dalam motivasi belajarnya karena guru BK bukan hanya memberikan informasi atau sosialisasi saja melainkan diiringi dengan praktiknya agar peserta didik lebih mudah memahami dan mengerti apa yang di sampaikan oleh guru tersebut. Ada beberapa kegiatan yang dilaksanakan guru BK untuk peserta didik yaitu sebagai berikut: (I) Tutor Sebaya XII, (2) Klinik Belajar Kelas XI, (3) Parenting, (4) Pelatihan Pik-R, (5) Klinik Belajar Kelas XI, (6) Museum/Duta SMADA, (7) Pencegah Narkoba Bekerjasama dengan BNN, (8) Pencegah Bullying, (9) Pencegah Penyalahgunaan IT, (10) Home Visit

\section{METODOLOGI PENELITIAN}

Pendekatan penelitian ini merupakan keseluruhan cara atau kegiatan yang dilakukan oleh peneliti dalam melaksanakan penelitian untuk mendapat suatu kesimpulan. Pendekatan pada penelitian ini ialah pendekatan kualitatif. 
Jurnal Bimbingan dan Konseling

Sugiyono (2013: 15) metode penelitian kualitatif adalah metode penelitian yang berdasarkan pada filsafat postpositivisme, digunakan untuk meneliti pada kondisi objek yang alamiah, (sebagai awalnya adalah eksperimen) dimana peneliti adalah sebagai instrumen kunci, pengambil sampel sumber data dilakukan secara purposive snowball, teknik pengumpulan dengan triangulasi (gabungan), analisis data induktif/kualitatif, dan hasil penelitian kualitatif lebih menekankan makna dari pada geeralisasi.

Jenis penelitian ini adalah penelitian studi kasus. Studi kasus sebagai suatu strategi penelitian digunakan dalam penelitian ini dengan beberapa alasan. Pertama, berkaitan dengan pertanyaan penelitian. Yin (dalam Yuliawan dan Himam, 2013: 6) menjelaskan bahwa studi kasus dapat digunakan untuk menjawab pertanyaan penelitian berupa bagaimana (how) dan mengapa (why). la berargumen bahwa kedua pertanyaan tersebut mengindikasikan perlunya eksplorasi terhadap permasalahan yang ingin dijawab melalui penelitian. Kedua adalah berkaitan dengan kontrol terhadap perilaku yang akan diteliti. Studi kasus umum digunakan ketika perilaku subyek yang akan diteliti tidak dapat dimanipulasi. Alasan ketiga berkaitan dengan fokus terhadap kontemporeritas. Diuraikan oleh Yin bahwa studi kasus memfokuskan diri untuk meneliti fenomena - fenomena yang cukup kontemporer.

Berdasarkan pendapat di atas, maka dapat disimpulkan bahwa studi kasus merupakan penelitian yang menyajikan pertanyaan berupa bagaimana dan mengapa, subjek yang akan diteliti oleh peneliti yang mengenai perilaku atau kondisi tertentu dalam kehidupan sehari - hari dan tidak dapat dimanipulasi/dipalsukan karena meneliti fenomena yang cukup kontemporer

\section{HASIL DAN PEMBAHASAN}

Berdasarkan informasi dari kepala sekolah dapat peneliti simpulkan bahwa memang benar guru BK sudah semaksimal mungkin memberikan informasi-informasi kepada peserta didik baik itu informasi mengenai belajar, pribadi, sosial, karir maupun yang lain itu selalu guru BK berikan dan mereka sebelum melakukannya pasti mereka menginfokan ke Kepala Sekolah dulu untuk memberikan yang terbaiknya bagaimana akan tetapi Bapak Kepala Sekolah tidak selalu bisa mengawasi apa yang guru BK lakukan tetapi itu bukan menjadi masalah karena beliau selalu mendapatkan hasil atau laporan dari guru BK tentang perkembangan peserta didik.

Berdasarkan beberapa informasi dari guru BK dapat disimpulkan oleh peneliti bahwa guru BK sudah berperan dalam hal pemberian layanan informasi, hal ini telah sesuai dengan teori yang disampaikan oleh Hidayat, dkk (2013: 4) yaitu: Layanan informasi merupakan layanan yang diberikan kepada seseorang dengan menyampaikan berita/informasi yang dapat digunakan sebagai bahan pertimbangan dan pengambilan keputusan untuk kepentingan peserta didik, pemecahan masalah, mencegah timbulnya masalah, dan untuk mengembangkan dan memelihara potensi yang ada. Berdasarkan penelitian guru BK di SMA N 2 Kota Tegal juga memberikan layanan karir guna membuat peserta didik untuk dapat memilih / melakukan perencanaan karir, hal ini sesuai dengan teori: Menurut Super dalam Winkel (dalam Richma Hidayat, 2015: 8) Salah satunya adalah kesulitan dalam pengambilan keputusan yang berkenaan dengan rencanarencana karier yang akan dipilihnya kelak. Salah satu tugas guru BK yaitu, membantu peserta didik mengembangakan karir yaitu bidang pelayanan yang membantu peserta didik dalam memahami dan menilai informasi, serta memilih dan mengambil keputusan. Berdasarkan penelitian guru BK kurang 
Jurnal Bimbingan dan Konseling

memberikan motivasi secara mendalam kepada pesea didik. Guru BK lebih banyak mengarahkan pemberian motivasi melalui pihak ketiga yang bekerjasama dengan pihak sekolah. Hal ini salah satunya dikarenakan guru BK sudah tidak masuk kedalam kelas. Menurut teori (Depdiknas, 2008: 61) sesuai rambu-rambu penyelenggaraan Bimbingan dan Konseling dalam jalur pendidikan formal, komptensi guru pembimbing tersebut adalah: a) memahami secara mendalam konseli yang hendak dilayani, b) menguasai landasan teoritik Bimbingan dan Konseling, c) menyelenggarakan Bimbingan dan Konseling yang memandirikan, d) mengembangkan pribadi dan profesionalitas secara berkelanjutan. Berdasarkan teori diatas maka dapat kita ketahui bahwa guru BK dalam melaksanakan tugasnya di sekolah, mereka lebih dominan dari pada pihak lain karena guru BK lebih memahami secara mendalam terkait dengan teori dan kepribadian peserta didik. Guru BK lah yang seharusnya berperan lebih besar kepada peserta didik untuk memberikan motivasi.

Berdasarkan beberapa informasi dari peserta didik dapat peneliti simpulkan bahwa guru BK sering memberikan layanan kepada peserta didik baik itu layanan informasi maupun layanan karir yang sering mereka berikan ketika peserta didik saat menghadapi UN maupun setelah lulus nanti mau kemana, guru BK selalu memberikan informasiinformasi tersebut kepada peserta didik, agar peserta didik lebih giat lagi untuk mencapai apa yang mereka inginkan. Guru BK juga melakukan atau melaksanakan yang namanya tutor sebaya dan klinik belajar serta bekerjasama dengan guru mapel untuk membantu peserta didik yang mengalami kesulitan belajar dengan adanya klinik belajar dan tutor sebaya tadi peserta didik jadi lebih memahami apa yang guru nya sampaikan akan tetapi alangkah baiknya dapat ditinjau kembali karena tidak semua peserta didik mengetahui atau memahami apa yang di sampaikan guru BK dan bahkan ada juga peserta didik yang kurang mendapatkan informasi atau apa, apakah mungkin karena peserta didiknya kurang bersosialisasi atau bahkan kurang ingin tahu maka dari itu guru BK harus lebih jeli lagi apakah semua peserta didik sudah benarbenar mendapatkan informasi atau belum.

Hal ini dapat dismpulkan bahwa guru BK di SMA N 2 Kota Tegal telah melakukan perannya dengan cukup baik, sesuai dengan alur teori yag ada.

Peneliti simpulkan bahwa guru BK sering memberikan layanan kepada peserta didik baik itu layanan informasi, motivasi ataupun arahan yang sering mereka berikan ketika peserta didik saat menghadapi UN maupun setelah lulus nanti mau kemana, guru BK selalu memberikan informasi-informasi tersebut kepada peserta didik, agar peserta didik lebih berusaha lagi untuk mencapai apa yang mereka inginkan. Guru BK juga melakukan yang namanya tutor sebaya dan klinik belajar serta bekerjasama dengan guru mapel untuk membantu peserta didik yang mengalami kesulitan belajar dengan adanya klinik belajar dan tutor sebaya tadi peserta didik jadi lebih memahami apa yang mereka belum pahami dan mengerti.

Hampir setiap hari guru BK selalu memberikan informasi dan motivasi untuk peserta didik baik kelas $\mathrm{X}, \mathrm{XI}$, dan XII guru BK juga selalu mengingatkan dan memberikan arahan kepada peserta didik dari hal yang kecil hingga kehal yang besar, baik dalam segi kerapian berpakaian, tata cara belajar yang baik itu seperti apa, guru BK juga menyarankan kepada peserta didik untuk mengurangi kegiatan-kegiatan yang banyak memakan waktu belajar mereka seperti pramuka dll. Agar mereka lebih mempunyai banyak waktu belajar untuk mempersiapkan apa yang seharusnya mereka siapkan seperti ulangan harian, semesteran, maupun Ujian Nasional. 


\section{KESIMPULAN}

Guru BK di SMA N 2 Kota Tegal telah melakukan peranannya dengan cukup optimal untuk meningkatkan motivasi belajar peserta didik dalam menghadapi Ujian Nasional. Hal ini dilakukan dengan adanya pemberian layanan informasi tentang memberikan dorongan atau memberikan arahan agar peserta didik lebih giat lagi dalam belajar untuk mendapatkan hasil yang diinginkan atau didapatkan ketika UN nanti. Pemberian motivasi kepada peserta didik lebih dilakukan oleh pihak ke 3 yang bekerjasama dengan pihak sekolah, yang belum maksimal diakukan oleh guru BK.

\section{DAFTAR PUSTAKA}

Hidayat, Richma. 2015. Layanan Informasi Karir Membantu Peserta Didik Dalam Meningkatkan Pemahaman Karir. Muria Kudus. ISSN 2460-I I 87

Hidayat, Hafiz, dkk. 2013. Profil Siswa Agresif Dan Peranan Guru Bimbingan Dan Konseling. Padang. Volume 2 No. I

Miru, Alimuddin S. 2009. Hubungan Antara Motivasi Belajar Terhadap Prestasi Belajar Mata Diklat Instalasi Listrik Siswa Smk Negeri 3 Makassar. Volume I, Nomor I

Sugiyono.2013. Metode Penelitian Pendidikan. Bandung: CV. Alfabeta

Yanti, Irma. 20I5. Pengaruh Respon Siswa Dan Peran Guru Bk Terhadap Pendidikan Karakter Pada Kelas X Di Madrasyah Aliyah 3 Banjarmasin. ISSN 2460 9722 Vol. I No I

Yuliawan, Teddi Prasetya dan Himam, Fathul. The Grasshopper Phenomenon: Studi Kasus Terhadap Profesional yang Sering Berpindah - pindah Pekerjaan. Jogjakarta. ISSN: 02I5-8884 VOLUME 34, NO. I. 